\section{BRAZIULIAN JOURNAL \\ OF MEDICAL AND BIOLOGICAL RESHARCH}

www.bjournal.com.br
ISSN 0100-879X

Volume 43 (12) 1135-1244 December 2010

BIOMEDICAL SCIENCES

AND

CLINICAL INVESTIGATION

Braz J Med Biol Res, December 2010, Volume 43(12) 1143-1152

doi: 10.1590/S0100-879X2010007500126

5-Bromo-2'-deoxyuridine induces visible morphological alteration in the DNA puffs of the anterior salivary gland region of Bradysia hygida (Diptera, Sciaridae)

J.C. de Almeida, H. Sauaia and J.C. Viana

The Brazilian Journal of Medical and Biological Research is partially financed by

Q

Ministério Conselho Nacional de De
cientifico e Tecnológico

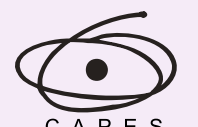

C A P E S
Ministério da Educação

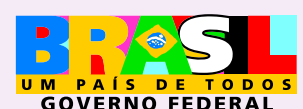

GOVERNO FEDERAL

\section{TFAPESP}

Institutional Sponsors
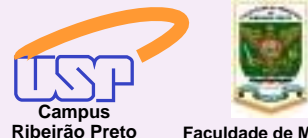

Ф SHIMADZU

GE Healthcare
Hotsite of proteomics metabolomics developped by:

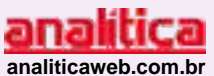

Thermo
SCIENTIFIC 


\title{
5-Bromo-2'-deoxyuridine induces visible morphological alteration in the DNA puffs of the anterior salivary gland region of Bradysia hygida (Diptera, Sciaridae)
}

\author{
J.C. de Almeida, H. Sauaia and J.C. Viana \\ Departamento de Biologia Celular e Molecular e Bioagentes Patogênicos, \\ Faculdade de Medicina de Ribeirão Preto, Universidade de São Paulo, Ribeirão Preto, SP, Brasil
}

\begin{abstract}
5-Bromo-2'-deoxyuridine (BrdUrd) has long been known to interfere with cell differentiation. We found that treatment of Bradysia hygida larvae with BrdUrd during DNA puff anlage formation in the polytene chromosomes of the salivary gland S1 region noticeably affects anlage morphology. However, it does not affect subsequent metamorphosis to the adult stage. The chromatin of the chromosomal sites that would normally form DNA puffs remains very compact and DNA puff expansion does not occur with administration of 4 to $8 \mathrm{mM}$ BrdUrd. Injection of BrdUrd at different ages provoked a gradient of compaction of the DNA puff chromatin, leading to the formation of very small to almost normal puffs. By immunodetection, we show that the analogue is preferentially incorporated into the DNA puff anlages. When BrdUrd is injected in a mixture with thymidine, it is not incorporated into the DNA, and normal DNA puffs form. Therefore, incorporation of this analogue into the amplified DNA seems to be the cause of this extreme compaction. Autoradiographic experiments and silver grains counting showed that this treatment decreases the efficiency of RNA synthesis at DNA puff anlages.
\end{abstract}

Key words: DNA puffs; BrdUrd; Gene amplification; Polytene chromosomes; Salivary glands; Sciaridae

\section{Introduction}

5-Bromo-2'-deoxyuridine (BrdUrd), an analogue of thymidine (dThd), is normally incorporated into DNA as 5-bromouracil in place of thymine. Although BrdUrd does not seem to affect cell growth at low doses, it is known to disturb a number of biological functions. Various studies have shown that BrdUrd can induce or inhibit cellular differentiation. For example, BrdUrd was reported to induce alkaline phosphatase (1), prolactin (2), interferon $\beta$ (3), and integrin (4) production in cultured cells. It induces differentiation of a cultured human small cell lung cancer cell line (5) and activates senescence-associated genes in human cells (6). BrdUrd also inhibits cell differentiation in vitro, including myogenesis (7-9), chondrogenesis (10), and erythrogenesis (7).

In spite of considerable efforts, the molecular target or mechanism for BrdUrd activity remains a mystery (11). Cell differentiation in the salivary glands of Sciaridae involves a process of gene amplification. When trancriptionally activated, the amplified genes cause the chromatin at these chromosomal sites to unwind, resulting in very large structures called DNA puffs (12). In Bradysia hygida, the process of gene amplification starts at the same time at all chromosome sites (age E3) that later will form DNA puffs, in the anterior (S1) and posterior (S3) regions of the salivary gland. About $20 \mathrm{~h}$ later, at age E7, the first group of DNA puffs becomes transcriptionally active; 6 to $7 \mathrm{~h}$ after that, these puffs have already receded. At E7+12h, the second group of DNA puffs starts to expand and these puffs remain transcriptionally active until about $E 7+24 \mathrm{~h}$, near the time of the pupal molt $(13,14)$. Additional DNA synthesis is very intense at these sites. The last cycle of normal replication is terminating, which makes DNA puff anlages a preferential target for BrdUrd incorporation. Bradshaw and Papaconstantinou (15) showed by autoradiography that the DNA puffs of Rhynchosciara incorporate much more BrdUrd than the rest of the chromosomal DNA. This should make this

Correspondence: J.C. de Almeida, Departamento de Biologia Celular e Molecular e Bioagentes Patogênicos, FMRP, USP, Av. Bandeirantes, 3900, 14049-900 Ribeirão Preto, SP, Brasil. Fax: +55-16-3633-1748. E-mail: jcdalmei@fmrp.usp.br

Received August 1, 2010. Accepted October 27, 2010. Available online November 12, 2010. Published December 20, 2010. 
system useful to detect morphological effects of BrdUrd on the chromatin and to study how BrdUrd affects the activity of specific genes.

Here, we show that if BrdUrd is injected at a concentration of $8 \mathrm{mM}$ or less into larvae of $B$. hygida during the period of gene amplification, adults are produced at the same frequency as when larvae are injected with water. However, injection of 4 to $8 \mathrm{mM}$ during the first half of the gene amplification period has a notable effect on the DNA puff anlages. The chromatin remains compact, and the DNA puffs do not expand. RNA puffs were also examined and seemed to be unaffected by BrdUrd treatment. It was also shown that BrdUrd incorporation is much more extensive into the DNA puff anlages than into the rest of the chromosomes. RNA synthesis is hindered at chromosomal sites that would normally form DNA puffs. These effects appear to be a consequence of BrdUrd incorporation into the amplified DNA. The present results indicate that in some instances, in other systems, the inhibitory effects of BrdUrd on the activity of specific genes can be due to a localized and irreversible chromatin compaction. These morphological observations are the basis for a molecular investigation that is presently underway.

\section{Material and Methods}

\section{Bradysia hygida}

B. hygida is maintained in our laboratory at $20^{\circ} \mathrm{C}$ and its life cycle lasts about 36 days. From hatching to the pupal molt, the larvae go through four instars. The last instar begins on the 12th day after hatching. On the 6th day of the fourth instar eyespots appear, which serve as useful age landmarks (14). We worked with fourth-instar female larvae. A pair of salivary glands, about $10 \mathrm{~mm}$ long, is characteristic of larvae at the end of the fourth instar. These glands consist of two rows of cells with three morphologically distinct regions: S1 (anterior), S2 (granulosa), and S3 (posterior). About 190 cells form each gland and about 45 of these are in the $\mathrm{S} 1$ region (14). The chromosomes are named $A, B, C$, and $X$. A chromosomal puff is identified by the name of its chromosome, followed by a number that refers to the chromosome segment. Eyespot pattern E3 (8th day of the fourth instar) coincides with the beginning of DNA puff anlage formation. Eighteen hours later (eyespot pattern E5), the first group of DNA puffs starts its expansion (DNA puffs C7, C5, and C4). After $2 \mathrm{~h}$, the E7 pattern is attained and at $E 7+8 \mathrm{~h}$ all puffs have receded. Expansion of the second group of DNA puffs starts at E7+12h (DNA puffs A14, B3d, C6, and X4). These puffs close before the pupal molt $(E 7+26 h)$, with the exception of DNA puff B3d. DNA puff B10 is the only one active between the periods of expansion of the first and second groups of DNA puffs, reaching maximal expansion at E7+8h. The DNA puffs are present in the S1 and S3 regions, though DNA puff $\mathrm{C} 7$ is only formed in the $\mathrm{S} 1$ region. The first group of DNA puffs does not form in the S2 region: the puffs of the second group are very inconspicuous in this gland region.

\section{Injection of solutions into the larvae}

Larvae were injected (14) with $1.0 \mu \mathrm{L}$ water or aqueous solutions of either BrdUrd or dThd, or both at different times after the beginning of age E3. The time from injection until the larvae attained age E7 was recorded.

\section{Polytene chromosome preparations}

After dissection, the S1 salivary gland regions were fixed for $2 \mathrm{~h}$ at room temperature in $7 \%$ perchloric acid (PCA) (13) and then squashed in a drop of $50 \%$ acetic acid using gelatinized slides and siliconized coverslips. Alternatively, this material was maintained in $7 \%$ PCA from hours to weeks at $-18^{\circ} \mathrm{C}$, and then it was squashed. The chromosome preparations were photographed under phase contrast with a Standard Universal model Zeiss microscope (Carl Zeiss, Germany).

We made a modification in the methods of immune detection of BrdUrd-substituted DNA in an attempt to obtain a better morphological result. The $\mathrm{S} 1$ salivary gland regions were fixed in 7\% PCA and squashed as previously described. After freezing in liquid nitrogen, the coverslips were removed and the slides were stored in cold $70 \%$ ethanol until use.

\section{Autoradiography}

In these experiments, after a sufficient time for radioactive precursor incorporation, the larvae were dissected on glass slides. The S1 regions were separated from the rest of the salivary glands, dragged into a drop of $50 \%$ acetic acid and squashed. The rest of the procedure for autoradiography and photomicrography was carried out according to Sauaia et al. (13). The autoradiographic grains were counted with the Standard Universal model Zeiss microscope, equipped with a Neofluar 100X objective, Kpl 8 X oculars, and an ocular reticulum containing 0.5 by $0.5 \mathrm{~mm}$ squares.

\section{Indirect immune detection of BrdUrd-substituted DNA}

The chromosome preparations were removed from the cold ethanol and washed with PBS. In an initial experiment the slides were divided into two groups; in one of them DNA was denatured by treatment with $2 \mathrm{~N} \mathrm{HCl}$ at $37^{\circ} \mathrm{C}$, for $30 \mathrm{~min}$ and in the other the slides were not treated. The preparations were washed with PBS and blocked with 50 $\mu \mathrm{L}$ blocking solution (PBS, $\mathrm{pH} 7.4,2 \%$ BSA, 0.1\% Tween 20) for $15 \mathrm{~min}$ at $37^{\circ} \mathrm{C}$. The blocking solution was removed and $50 \mu \mathrm{L}$ monoclonal Anti-BrdUrd antibody (Sigma-Aldrich, USA) diluted 1:500 in blocking solution (PBS, pH 7.4, 1\% BSA, $0.1 \%$ Tween 20 ) was applied to the preparations. These were then incubated for $2 \mathrm{~h}$ at $37^{\circ} \mathrm{C}$ and washed with PBS. The preparations were treated with a secondary Alexa 594-coupled goat anti-mouse immunoglobulin 
(1:300; Invitrogen, Molecular Probes, USA) and $1.25 \mu \mathrm{g} /$ $\mathrm{mL}$ diamidino-phenyl-indole (DAPI) in blocking solution for $2 \mathrm{~h}$ at room temperature. The slides were mounted in Fluoromount G (Electron Microscopy Sciences, USA). The preparations were then washed three times with $0.1 \%$ Tween 20 in PBS (30 min) and photographed with a fluorescence microscope Olympus BX50F4 (Olympus Optical Co., Ltd., Japan) equipped with a digital camera RT3 2Mp Slider and the software Spot version 4.7 (Diagnostic Instruments, Inc., USA). As expected, the results were morphologically much better without the $\mathrm{HCl}$ treatment. Chromosome fixation with 7\% PCA yields morphologically high-quality chromosomes, with denatured DNA, which is essential for the BrdUrd immune detection. In a second experiment, the $\mathrm{HCl}$ treatment was not carried out.

\section{Drugs}

BrdUrd and dThd were from Sigma-Aldrich. [5-3 $\mathrm{H}]-2^{2}-$ Deoxycytidine $\left(\left[{ }^{3} \mathrm{H}\right]-d \mathrm{Cyd}\right)$ and $\left[5^{3} \mathrm{H}\right]$-uridine $\left(\left[{ }^{3} \mathrm{H}\right]-\mathrm{Urd}\right)$ were from Amersham Life Science Ltd. (England).

\section{Results}

\section{Effect of different concentrations of BrdUrd on larva survival \\ We examined the effect of six concentrations of BrdUrd} on the survival of larvae treated at age E3 (20 larvae in each group). In two initial trials, $1 \mu \mathrm{L} 3.3,6.6,13.2$, and 20 $\mathrm{mM}$ concentrations were tested; in the next two, we used 8 and $10 \mathrm{mM}$. In each trial, control larvae were injected with water. The larvae were maintained in culture containers in the dark. These experiments demonstrated that injection with $8 \mathrm{mM}$ or less BrdUrd solution does not affect the number of adults formed [water $=90.9 \%$; BrdUrd (from 3.3 to $8 \mathrm{mM})=89.2 \%$ ]. The concentration of $10 \mathrm{mM}$ produced a similar result (87\%) while 13.2 and $20 \mathrm{mM}$ were more deleterious ( 46 and $43 \%$ of adults formed, respectively). There was no change in the time to metamorphosis in the groups treated with the analogue, and anatomic anomalies were rare, in contrast to what is obtained with treatment with hydroxyurea (13). Small imperfections in the legs or wings were observed at a low frequency in both control and experimental animals.

\section{Effect of BrdUrd on DNA puff development}

Four morphological experiments were performed to examine the effect of $8 \mathrm{mM} \mathrm{BrdUrd}$ on DNA puff development. In each experiment, three groups of 10 to 20 larvae were treated with $8 \mathrm{mM}$ BrdUrd, $8 \mathrm{mM}$ dThd or water. The injections were made during DNA puff anlage formation (larvae at age E3 or a little older; a period of about $20 \mathrm{~h}$ separates age E3 from age E7, when the first group of DNA puffs is expanded). The time taken to attain age $E 7$ was recorded, and the S1 regions were processed for squash preparations. There were no apparent differences in DNA puff morphology between larvae injected with water versus dThd solution, except that sometimes the puffs treated with dThd seemed smaller. In our experiment, the decrease in DNA puff size was probably due to partial DNA synthesis inhibition due to excess dThd (16). In the subsequent experiments, only larvae injected with dThd were used as controls.

The solution of $8 \mathrm{mM}$ BrdUrd administered during the period of 18 to $10 \mathrm{~h}$ before age E7 had a noticeable effect on all DNA puff anlages, preventing their expansion. They remained very compact, with typical features. This compaction differs from the appearance of the normal anlages or receded puffs (results not shown).

Next, a series of experiments was carried out using lower concentrations of BrdUrd. The 6 and $4 \mathrm{mM}$ solutions, injected during the same period, produced the same results as the $8 \mathrm{mM}$ solution (Figures 1 and 2). Figure 3 shows the DNA puff forming chromosomal regions C4 and C5 at high magnification. The $2 \mathrm{mM}$ solution either gave results similar to those of the higher concentrations, or the results were mitigated; the $1 \mathrm{mM}$ solution did not compact the DNA puff anlages.

We also studied the effect of this analogue injected at other times. If BrdUrd is injected from 4 to $5 \mathrm{~h}$ before age $E 7$, the first group of DNA puffs expands, but they are small and have an abnormal appearance. There is no expansion of either the second group of DNA puffs or of DNA puff B10 (results not shown).

Injection of BrdUrd $1 \mathrm{~h}$ before age E7 did not prevent expansion of DNA puffs. However, they seemed smaller and did not have the same appearance as the control puffs (results not shown). When the analogue was injected about $20 \mathrm{~h}$ before age E7, the results were heterogeneous. The DNA puffs looked normal when the injection was made 24 $\mathrm{h}$ before age $\mathrm{E} 7$.

\section{Effect of BrdUrd on the RNA puffs}

Numerous RNA puffs form in the four chromosomes throughout the larval phases. Some of those puffs are useful landmarks for determining larval age. Thirty RNA puffs were observed. There was no evidence of alterations in the texture or in the time of expansion. Some of these RNA puffs are indicated in Figures 1 and 2.

\section{Evidence that the effect of BrdUrd on the DNA puff anlages depends on analogue incorporation into the DNA}

Usually, the in vivo and in vitro effects of BrdUrd on the activity of genes characteristic of specialized cells depend on this analogue's incorporation into the DNA. We examined whether the effect of BrdUrd on the development of DNA puffs is due to its incorporation into the DNA.

We sought to produce conditions that would avoid or reduce BrdUrd incorporation into the polytene chromosomes. Injection of a mixture of BrdUrd and dThd offers a way to test whether BrdUrd continues to exert its effect 
on DNA puff development under conditions adverse to its incorporation.

Three groups of 20 larvae were injected with $4 \mathrm{mM}$ BrdUrd or $4 \mathrm{mM}$ BrdUrd $+4 \mathrm{mM}$ dThd and larvae that attained age E7 between 16 and $12 \mathrm{~h}$ after injection were selected for cytological examination. Larvae treated with the nucleoside mixture presented expanded DNA puffs characteristic of this age (results not shown).
The experiments described in the previous paragraph were repeated. Two, 4 and $6 \mathrm{~h}$ after injection, the salivary gland $\mathrm{S} 1$ regions were prepared for in situ immune detection of BrdUrd-substituted DNA. Six hours after the injection, it was clear that BrdUrd actually was incorporated into the DNA, and this only occurred when BrdUrd was injected alone (Figure $4 \mathrm{a}$ and $\mathrm{b}$ ). As expected, BrdUrd incorporation into the DNA puff anlages was much greater than
dThd

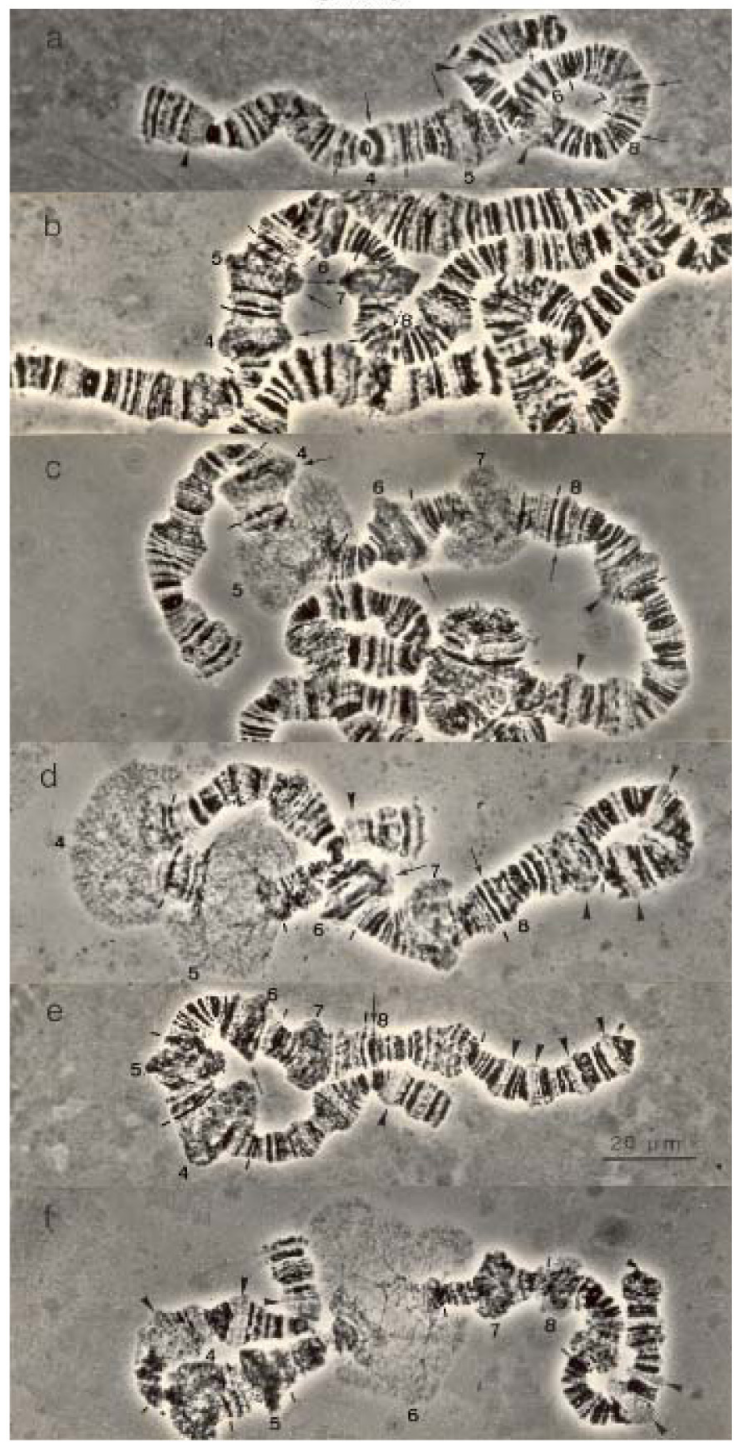

Brdurd

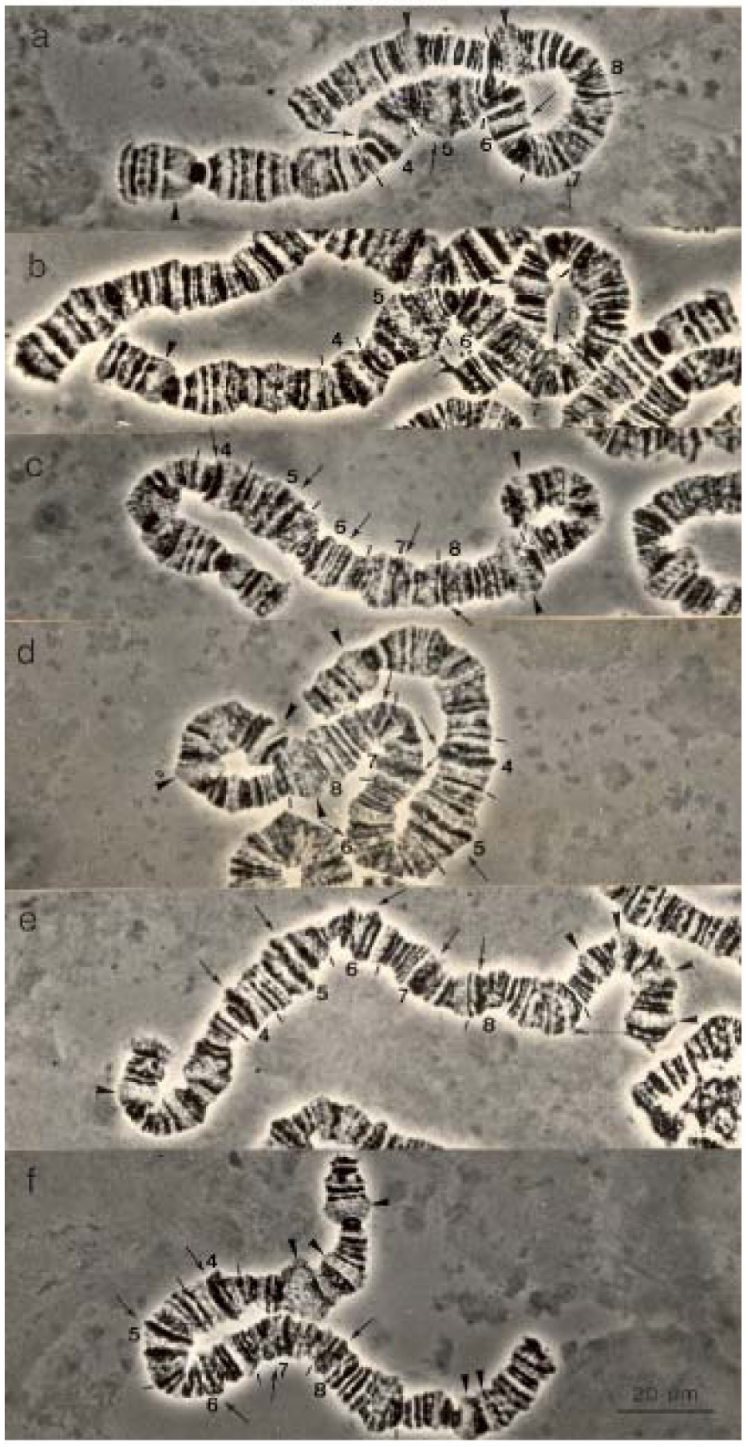

Figure 1. Effect of BrdUrd on chromosome C DNA puff development in the S1 salivary gland region of Bradysia hygida larvae. Left side photos show chromosomes of larvae treated with $4 \mathrm{mM}$ dThd, and right side photos show chromosomes of larvae treated with $4 \mathrm{mM} \mathrm{BrdUrd}$. The larvae were injected with one of the nucleosides between 18 and $15 \mathrm{~h}$ before age $\mathrm{E} 7$ and were dissected at different times after injection: $a, 1 \mathrm{~h} ; b, 10 \mathrm{~h} ; c, 1 \mathrm{~h}$ before age $\mathrm{E} 7 ; d, \mathrm{E} 7+2 \mathrm{~h} ; e, \mathrm{E} 7+6 \mathrm{~h} ; f, \mathrm{E} 7+16 \mathrm{~h}$. Chromosomal regions C7, C5 and C4 form DNA puffs of the first group; region C6 forms puffs of the second group. The DNA puff anlages are indicated by arrows. Several RNA puffs are indicated by arrowheads. All the DNA puff anlages remained compacted at all ages. The pattern of RNA puffs seemed to be the same in both materials. dThd = thymidine; BrdUrd = 5-bromo-2'-deoxyuridine. Bar: $20 \mu \mathrm{m}$. 
into the rest of the chromosomes. In these experiments we introduced the use of $7 \%$ PCA as a fixative for improved chromosome preparation. This treatment also promotes
DNA denaturation, essential for immune detection of BrdUrd-substituted DNA.

The results of these experiments support the hypothesis
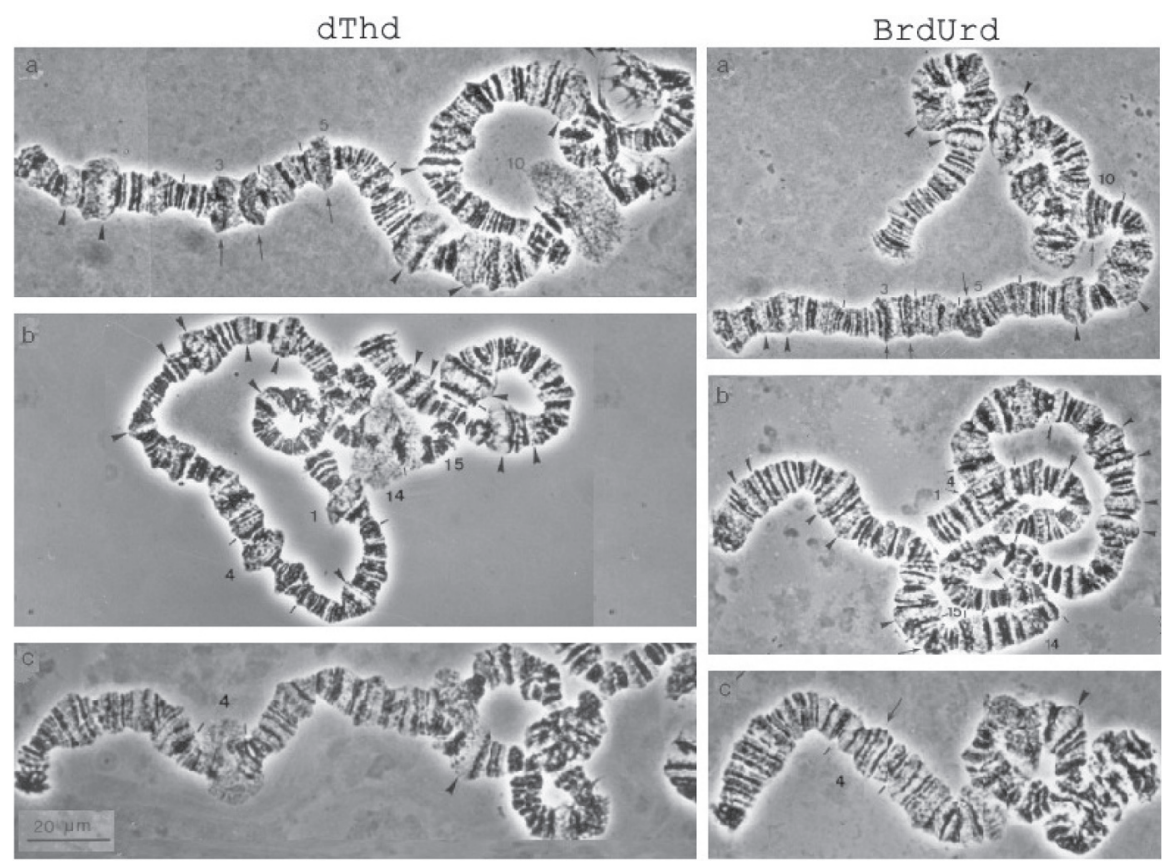

Figure 2. Chromosomes $B(a), A(b)$ and $X(c)$ from salivary gland material treated with dThd (left side) or with BrdUrd (right side) under the same experimental conditions as described for Figure 1. Here we show the chromosomes only at the age when the main DNA puffs are in maximal expansion. a, $\mathrm{E} 7+6 \mathrm{~h} ; b, \mathrm{E} 7+16 \mathrm{~h}$, and $c, \mathrm{E} 7+14 \mathrm{~h}$. dThd $=$ thymidine; BrdUrd $=5$-bromo2'-deoxyuridine. Bar $=20 \mu \mathrm{m}$.

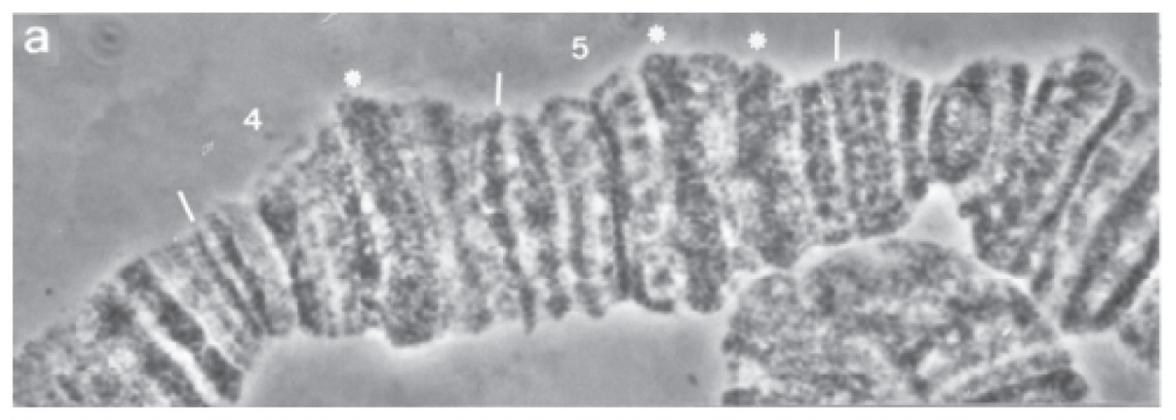

Figure 3. Morphological details of the C4 and C5 DNA puff anlages at high magnification. a, BrdUrd-treated and $b$, dThd-treated chromosomes. The 4-mM solutions were injected between 16 and $18 \mathrm{~h}$ before age E7. The larvae were dissected at age $E 7+2 \mathrm{~h}$. dThd = thymidine; BrdUrd = 5-bromo2'-deoxyuridine.

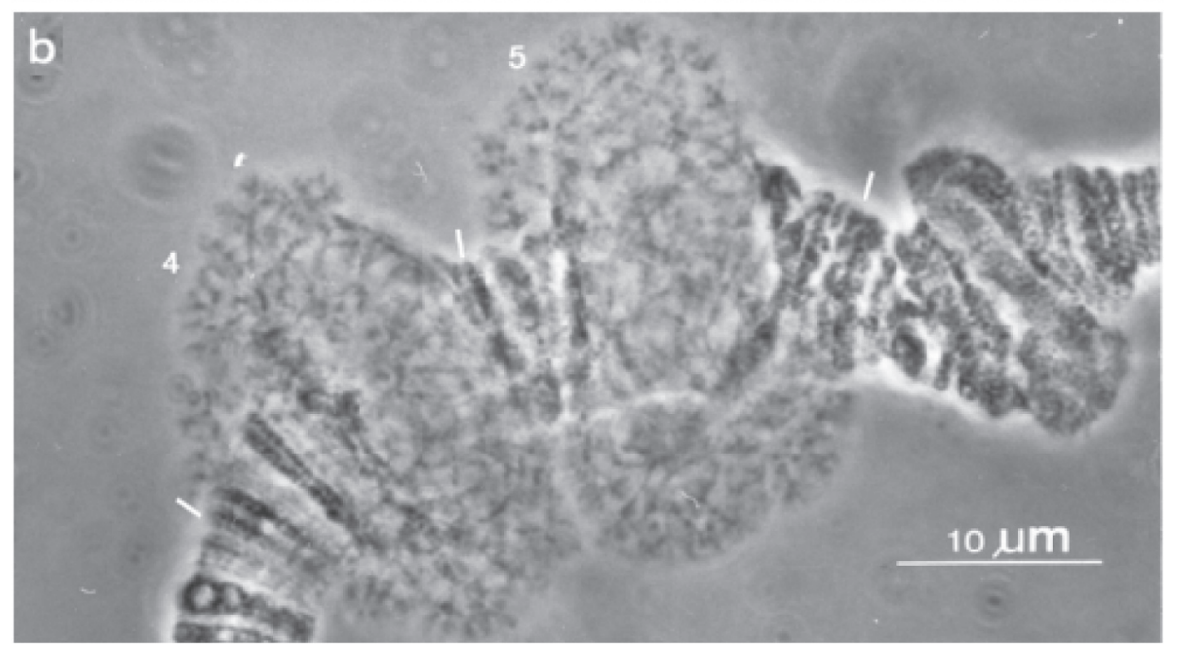

www.bjournal.com.br 
that the effect of BrdUrd on DNA puff anlage expansion depends on its incorporation into the DNA. It is not impossible, but it is improbable that BrdUrd exerts its effect through other mechanisms that would be influenced by dThd.

\section{Effect of BrdUrd on the incorporation of $\left[{ }^{3} \mathrm{H}\right]-d C y d$ : autoradiographic observations}

DNA synthesis was investigated under the experimental conditions used. The incorporation of $\left[{ }^{3} \mathrm{H}\right]-d$ Cyd into chromosomal sites that form DNA puffs was studied in
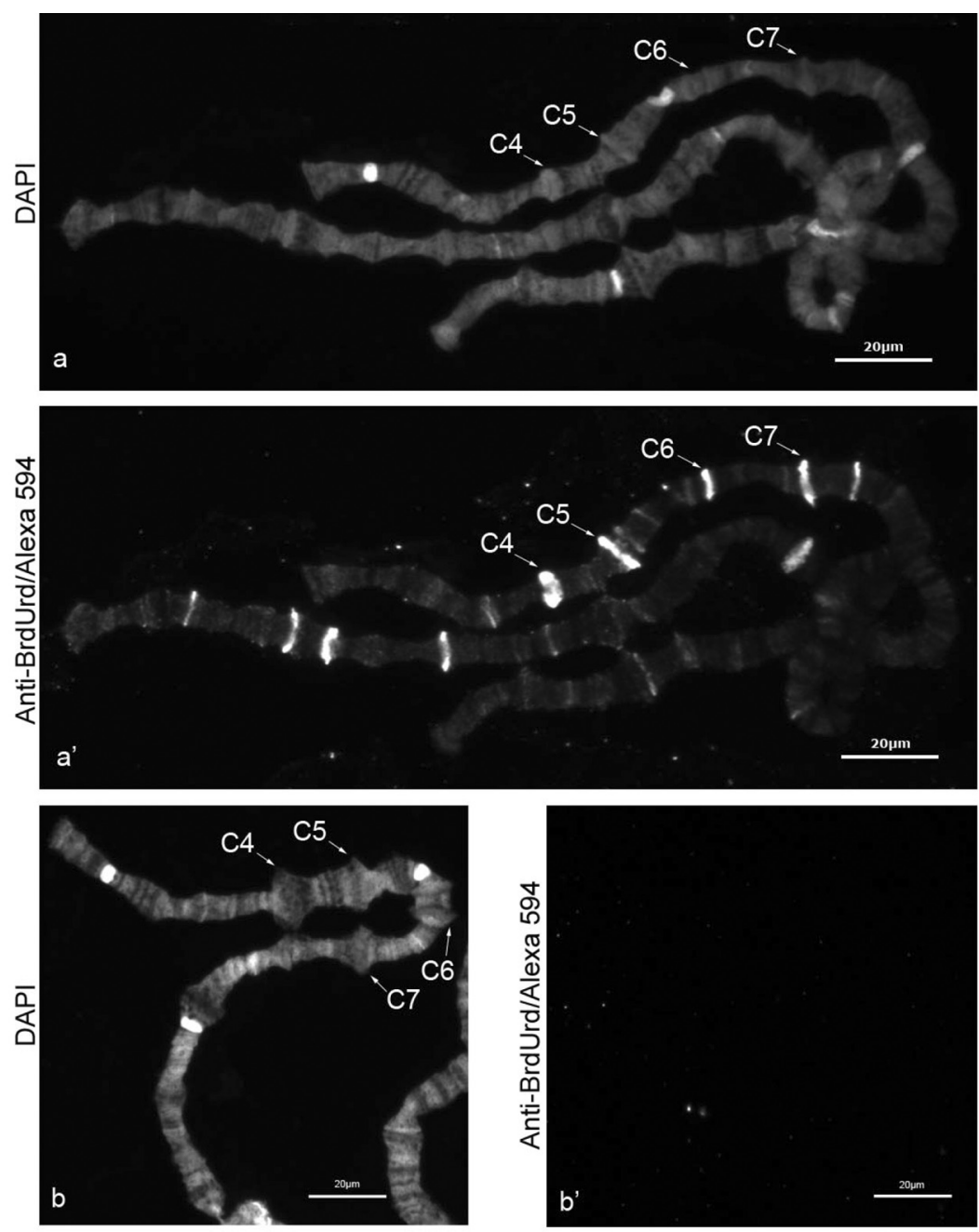

Figure 4. The addition of dThd to the BrdUrd solution suppresses the incorporation of the analogue into the DNA. Here this effect is shown for chromosome C. a, Material treated with $4 \mathrm{mM}$ BrdUrd; the chromosomes were stained with DAPI; a', the same chromosome showing the indirect immunodetection of BrdUrd-substituted DNA (antiBrdUrd + anti-mouse labeled with Alexa 594). $b$ and $b$ ', Material treated with $4 \mathrm{mM}$ BrdUrd + $4 \mathrm{mM}$ dThd; the chromosomes were stained as in $a$ and $a$ '. The solutions were injected at about $12 \mathrm{~h}$ before age E7 and the larvae were dissected $6 \mathrm{~h}$ later. The DNA puff-forming chromosomal regions in chromosome $\mathrm{C}$ are numbered. Anlages from chromosome $\mathrm{B}$ are also evident in $b$. BrdUrd = 5-bromo-2'-deoxyuridine; $\mathrm{dThd}=$ thymidine; DAPI = diamidino-phenyl-indole. Bar $=20 \mu \mathrm{m}$. two autoradiographic experiments. Larvae divided into two groups of 15 were injected with solutions of $4 \mathrm{mM}$ dThd or $4 \mathrm{mM}$ BrdUrd. Those larvae that attained age E7 after and prepared for squash and autoradiography. In both experiments, incorporation of $\left[{ }^{3} \mathrm{H}\right]-d C y d$ throughout the chromosomes, in the regions that do not form DNA puffs, apparently did not differ between the control and treatment groups. This was confirmed when we counted the number of silver grains in a chromosomal region that does not form DNA puffs (C1a,b). The mean numbers of grains in that region in the control (20 chromosomes from six larvae) and treatment (18 chromosomes from six larvae) groups were similar (90 and 88, respectively). In the DNA puff-forming sites, the grains were not counted because the high labeling density prevented counting (Figure $5 c$ and $d$ ). It cannot be excluded that BrdUrd caused a drop in $\left[{ }^{3} \mathrm{H}\right]$-dCyd incorporation at DNA puff anlages. If there is inhibition of total DNA synthesis due to the action of BrdUrd, this inhibition must be similar to that provoked by dThd.

\section{Effect of BrdUrd on the incorporation of [ $\left.{ }^{3} \mathrm{H}\right]-U r d:$ autoradiographic observations}

Transcriptional activity was studied autoradiographically in the chromosome sites that form DNA puffs. Two experiments similar to those in the preceding section were performed, this time using $\left[{ }^{3} \mathrm{H}\right]$-Urd as the radioactive precursor. Incorporation of $\left[{ }^{3} \mathrm{H}\right]$-Urd was preferentially decreased in those chromosomal sites that form DNA puffs; they did not expand because of BrdUrd activity (Figure $5 a$ and $b$ ). This assertion was confirmed by counting the silver grains in chromosome regions $\mathrm{C} 1 \mathrm{a}, \mathrm{b}$ (which do not form DNA puffs) and C4 (which form a typical DNA puff). In each of six squash preparations, grains from those regions in five chromosomes were counted and the mean values were calculated. The same was done for the control group. For larvae treated with dThd, the labeling ratio between regions C4/C1a,b (339.1/47.8) was 7.1. For the BrdUrd-treated larvae the ratio was 2.1 (97.2/45.4). 


\section{Discussion}

If larvae at age E3 (between 24 and $16 \mathrm{~h}$ before age E7) are injected with $1 \mu \mathrm{L}$ of a BrdUrd solution at a concentration of $8 \mathrm{mM}$ or less, they will develop into healthy adult flies, in numbers similar to those produced from larvae treated with water, without a significant delay in development. Notably, opposite to what occurs due to treatment with BrdUrd, treatment of larvae at the same age with hydroxyurea, a potent DNA synthesis inhibitor, causes diverse and serious anomalies in the adults that develop from these larvae (13). It seems clear, therefore, that under these conditions BrdUrd has little or no effect on imaginal disc development, while the DNA synthesis inhibitor strongly reduces such development.

\section{The effect of BrdUrd on DNA puff development}

The most interesting aspect of the results presented here is the selective inhibitory effect of BrdUrd on the development of DNA puffs. The anlages of these puffs fail to expand and seem to become more strongly compacted than normal when BrdUrd is administered at the proper age and concentration. The biological action of BrdUrd on the diverse materials was attributed to the effects of its incorporation into the DNA. This interpretation was confirmed for the system used here: 1) we showed that the analogue is incorporated into the DNA and, as expected, incorporation into the DNA puff anlages is much greater than into the rest of the chromosomes; 2) when BrdUrd is injected together with dThd, the analogue is not incorporated and the effect of BrdUrd is suppressed.

Thus, preferential inhibition of DNA puff development by BrdUrd can be explained based on the following properties of these puffs: a) they are accompanied and usually preceded by disproportionally high levels of DNA synthesis at the chromosomal sites in which they form; b) their development depends on DNAsynthesis occurring during anlage formation. Given these two assertions, we expect that DNA puff development is the preferential target for agents that modify the properties of synthesized DNA. Injection of BrdUrd at a suitable concentration and time permitted analogue incorporation into the additional DNA in amounts large enough to reduce DNA puff expansion. RNA puffs seem not to be affected. This was expected, since their expansion does not depend on de novo DNA synthesis and we could see that BrdUrd incorporation into the chromosomes was much lower than into the DNA puff anlages. RNA puffs also continue to form, even if total DNA synthesis is inhibited during the period of DNA puff anlage formation (13). Also, the overall increase in the amount of DNA in the S1 region during this period is only about $30 \%$ (Paçó-Larson ML, personal communication), while the amplified genes BhC4-1 (in DNA puff C4) and BhB10-1 (in DNA puff B10) increase

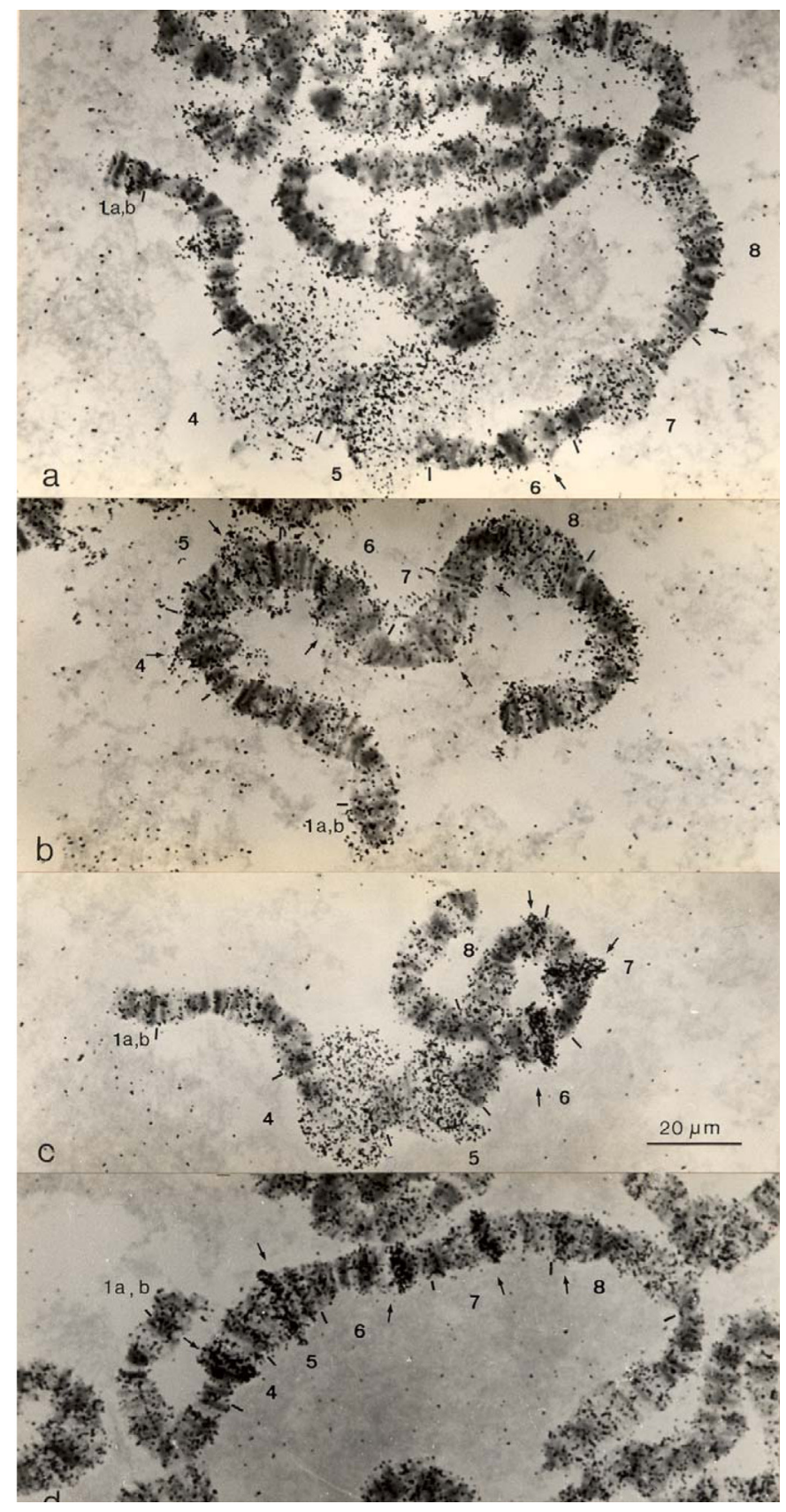

Figure 5. Effect of BrdUrd injected $15 \mathrm{~h}$ before age $\mathrm{E} 7$ on incorporation of $\left[{ }^{3} \mathrm{H}\right]$-Urd or $\left[{ }^{3} \mathrm{H}\right]-d C y d$ into chromosome $\mathrm{C}$ at age $\mathrm{E} 7$. Incorporation time: $1 \mathrm{~h}$ and $40 \mathrm{~min}$. a, $\left[{ }^{3} \mathrm{H}\right]$-Urd incorporation into control (treated with $4 \mathrm{mM}$ dThd) or $b$, experimental material (treated with $4 \mathrm{mM} \mathrm{BrdUrd})$, respectively. $\left[{ }^{3} \mathrm{H}\right]$-dCyd incorporation in control and experimental material (c) and (d), respectively. The arrows point to the different DNA puff anlages. $\left[{ }^{3} \mathrm{H}\right]$-Urd $=\left[{ }^{3} \mathrm{H}\right]$-uridine; $\left[{ }^{3} \mathrm{H}\right]$-dCyd $=$ $\left[5-{ }^{3} \mathrm{H}\right]$-deoxycytidine. Bar $=20 \mu \mathrm{m}$. 
22- and 10-fold, respectively $(17,18)$. The fact that RNA puffs are not altered by treatment with BrdUrd under these conditions can tentatively be explained by the possibility that the amount of analogue incorporated by these puffs, if it occurs, is insufficient to produce an appreciable functional effect. However, there are cases in which the behavior of RNA puffs is altered $(19,20)$. The most plausible explanation for the diversity of BrdUrd effects on chromosome puffs is that differences in the degree of local substitution occur and the various puffs differ in the mechanisms that control their expansion. Lin and Riggs (21) showed that incorporation of BrdUrd into the lactose operator changes its properties, making interaction with the repressor protein 10-fold more stable. David et al. (22), Lapeyre and Bekhor (23,24), Augenlicht et al. (25), and Gordon et al. (26) showed that BrdUrd also modifies the properties of DNA in the chromatin of different types of eukaryotic cells, probably increasing the stability of the interaction between DNA and chromosomal proteins. Lin et al. (27) have shown in vitro that different histones bind more strongly to BrdUrd-substituted DNA than to normal DNA.

Some researchers $(21,23,28)$ have proposed that BrdUrd promotes chromatin compaction in certain chromosomal sites that are involved in the control of synthesis of proteins typical of differentiated cells. The selective effect of BrdUrd on DNA puff anlages reported here seems to confirm these previsions and appears to constitute their first clear morphological demonstration.

A series of papers have shown an opposite effect of BrdUrd on compacted chromatin. BrdUrd very clearly induces a senescent-like phenomenon in every mammalian cell type and also in yeast cells $(6,29)$. These genes form clusters on or nearby Giemsa-stained bands of human chromosomes $(30,31)$. These results are consistent with the fact that BrdUrd decondenses particular regions of chromosomes (32), suppresses position-effect variegation (33), and induces expression of silenced genes (34). Moreover, AT-tract minor groove binders have been shown to markedly potentiate the effect of $\operatorname{BrdUrd}(30,35)$. Based on these and on current observations (11), it is suggested that BrdUrd targets certain types of AT-rich sequences and alters chromatin structure, disrupting nucleosome positioning by inducing A-form-like DNA conformation in yeast cells. It is clear that, despite considerable efforts, the molecular mechanisms for the different effects of BrdUrd are still unknown.

\section{Effect of BrdUrd on transcription in DNA puffs}

Treatment with BrdUrd under conditions that produce its typical effect on the DNA puff anlages provokes a strong decrease in $\left[{ }^{3} \mathrm{H}\right]$-Urd incorporation into the corresponding chromosome segments. This effect might be due to the incapacity of the anlages to expand and to the stronger compaction imposed on them. Also, it is possible that incorporation of BrdUrd into AT-rich sequences in the promoter or into the transcribed region of the gene directly affects the transcription process. This was previously proposed by others, such as Hill et al. (36). In mesophyl cells of Zinnia elegans that had impaired transdifferentiation into tracheary elements due to BrdUrd, 76 and $24 \%$ of the radioactivity of $\left[{ }^{3} \mathrm{H}\right]$-BrdUrd was incorporated into DNA and RNA, respectively. Consequently, part of the transcribed mRNA can also be damaged by incorporation of BrdUrd, which could contribute to the final effect of this analogue (16).

It is possible that in some other systems a similar localized and irreversible chromatin compaction provoked by BrdUrd can be the cause for specific gene activity inhibition.

All amplified genes that have been characterized encode structural proteins used to spin the cocoon, which protects the animal during pupal molt and metamorphosis. In our experimental system, in which the synthesis of those proteins is apparently suppressed, animal survival seems not be affected because their development occurred under laboratory conditions.

\section{Perspective}

This system can help with the study of several properties of chromatin in which DNA has incorporated BrdUrd, since it offers the possibility to visualize defined chromosomal sites. Within these, preferential analogue incorporation brings about modifications of a morphological and functional nature.

Currently, we have probes for the amplified genes BhC41 (17), BhC5-2 (unpublished results) and BhB10-1 (18), which are found at DNA puffs $C 4, C 5$, and B10, respectively. Probes for unamplified genes are also available such as $B h E c R$ (37) and BhMit/16S (38). Also, we have polyclonal antibodies specific for proteins BhC4-1 (39), BhB10-1 (40) and BhEcR (37). Therefore, it is possible to determine the effect of BrdUrd on defined genes based on its effect on chromatin morphology, mRNA synthesis and translation. Comparisons between these effects on amplified and unamplified genes would be useful. If changes in DNA properties occur under the effect of BrdUrd incorporation, we can use suitable primary antibodies for in situ immune detection to determine what happens to important components of the replication and transcription machinery (different histones, DNA polymerase, RNA polymerase II, transcription factor EcR, etc.). These studies are currently underway.

\section{Acknowledgments}

We thank Luis A.M. Andrade and Cláudia R. Maranghetti Faggion for dedicated technical assistance. We are indebted to Dr. David De Jong (Department of Genetics, Faculty of Medicine of Ribeirão Preto) for a critical reading of the manuscript and to Gabriela M. Zanarotti and William M.A. Maximiano for help with the figures. Research generously supported by grants from FAPESP and FAEPA. 


\section{References}

1. Koyama $\mathrm{H}$, Ono $\mathrm{T}$. Induction of alkaline phosphatase by 5-bromodeoxyuridine in a hybrid line between mouse and Chinese hamster in culture. Exp Cell Res 1971; 69: 468470.

2. Biswas DK, Abdullah KT, Brennessel BA. On the mechanism of 5-bromodeoxyuridine induction of prolactin synthesis in rat pituitary tumor cells. J Cell Biol 1979; 81: 1-9.

3. Shuttleworth J, Morser J, Burke DC. Control of interferon mRNA levels and interferon yields in butyrate and 5'-bromodeoxyuridine-treated Namalwa cells. J Gen Virol 1982; 58 (Part 1): 25-35.

4. Meleady P, Clynes M. Bromodeoxyuridine induces integrin expression at transcriptional (alpha2 subunit) and post-transcriptional (beta1 subunit) levels, and alters the adhesive properties of two human lung tumour cell lines. Cell Commun Adhes 2001; 8: 45-59.

5. Chen Y, Pacyna-Gengelbach M, Deutschmann N, Ye F, Petersen I. 5-Bromodeoxyuridine induced differentiation of a human small cell lung cancer cell line is associated with alteration of gene expression. Biochem Biophys Res Commun 2007; 353: 559-564.

6. Michishita E, Nakabayashi K, Suzuki T, Kaul SC, Ogino H, Fujii M, et al. 5-Bromodeoxyuridine induces senescence-like phenomena in mammalian cells regardless of cell type or species. J Biochem 1999; 126: 1052-1059.

7. Holtzer H, Mayne R, Weintraub H, Campbell G. Obligatory requirement for DNA synthesis during myogenesis, erythrogenesis and chondrogenesis. In: Pollak JK, Lee JW (Editors), The biochemistry of gene expression in higher organisms. Boston: Reidel Dordrecht; 1972. p 287-304.

8. Tapscott SJ, Lassar AB, Davis RL, Weintraub H. 5-Bromo2'-deoxyuridine blocks myogenesis by extinguishing expression of MyoD1. Science 1989; 245: 532-536.

9. Ogino H, Satou W, Fujii M, Suzuki T, He Y, Michishita E, et al. The human MYOD1 transgene is suppressed by 5-bromodeoxyuridine in mouse myoblasts. J Biochem 2002; 132: 953-959.

10. Abbott J, Holtzer H. The loss of phenotypic traits by differentiated cells, V. The effect of 5-bromodeoxyuridine on cloned chondrocytes. Proc Natl Acad Sci U S A 1968; 59: 1144-1151.

11. Miki K, Shimizu M, Fujii M, Hossain MN, Ayusawa D. 5-Bromouracil disrupts nucleosome positioning by inducing Aform-like DNA conformation in yeast cells. Biochem Biophys Res Commun 2008; 368: 662-669.

12. Breuer ME, Pavan C. Gens na diferenciação. Ciênc Cult 1952; 4: 141.

13. Sauaia H, Laicine EM, Alves MA. Hydroxyurea-induced inhibition of DNA puff development in the salivary gland chromosomes of Bradysia hygida. Chromosoma 1971; 34: 129-151.

14. Laicine EM, Alves MA, de Almeida JC, Rizzo E, Albernaz WC, Sauaia H. Development of DNA puffs and patterns of polypeptide synthesis in the salivary glands of Bradysia hygida. Chromosoma 1984; 89: 280-284.

15. Bradshaw WS, Papaconstantinou J. Differential incorporation of 5-bromodeoxyuridine into DNA puffs of larval salivary gland chromosomes in Rhynchosciara. Biochem Biophys Res Commun 1970; 41: 306-312.
16. Shoji $Y$, Sugiyama M, Komanine A. Suppression by 5-bromo2'-deoxyuridine of transdifferentiation into tracheary elements of isolated mesophyl cells of Zinnia elegans. Plant Cell Physiol 1996; 37: 401-403.

17. Paçó-Larson ML, Almeida JC de, Edström JE, Sauaia H. Cloning of a developmentally amplified gene sequence in the DNA puff C4 of Bradysia hygida salivary gland. Insect Biochem Mol Biol 1992; 22: 439-446.

18. Fontes AM, de-Almeida JC, Edstrom JE, Paco-Larson ML. Cloning of a B10 DNA puff sequence developmentally amplified and expressed in the salivary gland of Bradysia hygida. Braz J Med Biol Res 1992; 25: 777-780.

19. Boyd JB, Boyd SF. Influence of bromodeoxyuridine on the stability and function of polytene chromosomes. Chromosoma 1977; 61: 75-94.

20. Poluektova EV, Mitrofanov VG, Gauze GG. [Changes in the chromosomal puff spectrum of Drosophila virilis salivary glands exposed to 5-bromodeoxyuridine]. Dokl Akad Nauk SSSR 1975; 222: 720-722.

21. Lin SY, Riggs AD. Lac operator analogues: bromodeoxyuridine substitution in the lac operator affects the rate of dissociation of the lac repressor. Proc Natl Acad Sci U S A 1972; 69: 2574-2576.

22. David J, Gordon JS, Rutter WJ. Increased thermal stability of chromatin containing 5-bromodeoxyuridine-substituted DNA. Proc Natl Acad Sci U S A 1974; 71: 2808-2812.

23. Lapeyre JN, Bekhoe I. Effects of 5-bromo-2'-deoxyuridine and dimethyl sulfoxide on properties and structure of chromatin. J Mol Biol 1974; 89: 137-162.

24. Lapeyre JN, Bekhor I. Chromosomal protein interactions in chromatin and with DNA. J Mol Biol 1976; 104: 25-58.

25. Augenlicht L, Nicolini C, Baserga R. Circular dichroism and thermal denaturation studies of chromatin and DNA from BrdU-treated mouse fibroblasts. Biochem Biophys Res Commun 1974; 59: 920-926.

26. Gordon JS, Bell GI, Martinson HC, Rutter WJ. Selective interaction of 5'-bromodeoxyuridine substituted DNA with different chromosomal proteins. Biochemistry 1976; 15: 4778-4785.

27. Lin S, Lin D, Riggs AD. Histones bind more tightly to bromodeoxyuridine-substituted DNA than to normal DNA. Nucleic Acids Res 1976; 3: 2183-2191.

28. Walther BT, Pictet RL, David JD, Rutter WJ. On the mechanism of 5-bromodeoxyuridine inhibition of exocrine pancreas differentiation. J Biol Chem 1974; 249: 1953-1964.

29. Fujii M, Ito H, Hasegawa $\mathrm{T}$, Suzuki $\mathrm{T}$, Adachi $\mathrm{N}$, Ayusawa D. 5-Bromo-2'-deoxyuridine efficiently suppresses division potential of the yeast Saccharomyces cerevisiae. Biosci Biotechnol Biochem 2002; 66: 906-909.

30. Suzuki T, Michishita E, Ogino H, Fujii M, Ayusawa D. Synergistic induction of the senescence-associated genes by 5-bromodeoxyuridine and AT-binding ligands in HeLa cells. Exp Cell Res 2002; 276: 174-184.

31. Minagawa S, Nakabayashi K, Fujii M, Scherer SW, Ayusawa D. Functional and chromosomal clustering of genes responsive to 5-bromodeoxyuridine in human cells. Exp Gerontol 2004; 39: 1069-1078.

32. Zakharov AF, Baranovskaya LI, Ibraimov AI, Benjusch VA, Demintseva VS, Oblapenko NG. Differential spiralization 
along mammalian mitotic chromosomes. II. 5-Bromodeoxyuridine and 5-bromodeoxycytidine-revealed differentiation in human chromosomes. Chromosoma 1974; 44: 343-359.

33. Suzuki T, Yaginuma M, Oishi T, Michishita E, Ogino H, Fujii $M$, et al. 5-Bromodeoxyuridine suppresses position effect variegation of transgenes in HeLa cells. Exp Cell Res 2001; 266: 53-63.

34. Fan J, Kodama E, Koh Y, Nakao M, Matsuoka M. Halogenated thymidine analogues restore the expression of silenced genes without demethylation. Cancer Res 2005; 65: 6927-6933.

35. Satou W, Suzuki T, Noguchi T, Ogino H, Fujii M, Ayusawa D. AT-hook proteins stimulate induction of senescence markers triggered by 5-bromodeoxyuridine in mammalian cells. Exp Gerontol 2004; 39: 173-179.

36. Hill BT, Tsuboi A, Baserga R. Effect of 5-bromodeoxyuridine on chromatin transcription in confluent fibroblasts. Proc Natl
Acad Sci U S A 1974; 71: 455-459.

37. Candido-Silva JA, de Carvalho DP, Coelho GR, de Almeida JC. Indirect immune detection of ecdysone receptor (EcR) during the formation of DNA puffs in Bradysia hygida (Diptera, Sciaridae). Chromosome Res 2008; 16: 609-622.

38. Candido-Silva JA, Zanarotti GM, Gallina AP, de Almeida JC. Developmental regulation of BhSGAMP-1, a gene encoding an antimicrobial peptide in the salivary glands of Bradysia hygida (Diptera, Sciaridae). Genesis 2007; 45: 630-638.

39. Monesi N, Silva JA Jr, Martins PC, Teixeira AB, Dornelas $E C$, Moreira JE, et al. Immunocharacterization of the DNA puff BhC4-1 protein of Bradysia hygida (Diptera: Sciaridae). Insect Biochem Mol Biol 2004; 34: 531-542.

40. Fontes AM, Conacci ME, Monesi N, de Almeida JC, PacoLarson ML. The DNA puff BhB10-1 gene encodes a glycinerich protein secreted by the late stage larval salivary glands of Bradysia hygida. Gene 1999; 231: 67-75. 